\title{
Cardiopulmonary effects and eyeball centralization with low-dose atracurium in spontaneously breathing, anesthetized dogs
}

\author{
Avaliação cardiopulmonar e da centralização do globo ocular em cães com baixas doses de \\ atracúrio mantidos em anestesia inalatória sob ventilação espontânea
}

\author{
Adriano Bonfim Carregaro ${ }^{I}$ Gabrielle Coelho Freitas ${ }^{\text {II }}$ Fernando Silvério Ferreira da Cruz ${ }^{\text {II }}$ \\ Melissa MachadoII Guilherme Kanciukaitis Tognoli ${ }^{\text {II }}$ Ney Luis Pippi ${ }^{\text {II }}$
}

\section{ABSTRACT}

The objective was to determine the cardiopulmonary effects and eyeball centralization time obtained with 15 or $30 \mu \mathrm{g} \mathrm{kg}^{-1}$ of atracurium in anesthetized dogs under spontaneous breathing. Eighteen healthy adult mixed-breed dogs were used, which received $0.1 \mathrm{mg} \mathrm{kg}^{-1}$ acepromazine and $0.5 \mathrm{mg} \mathrm{kg}^{-1}$ morphine IM, followed by $4 \mathrm{mg}$ $\mathrm{kg}^{-1}$ propofol IV and maintained on isoflurane anesthesia with spontaneous breathing. Animals received $1 \mathrm{~mL} 0.9 \% \mathrm{NaCl} \mathrm{IV}$ (CG), $15 \mu \mathrm{g} \mathrm{kg-1}$ (G15) or $30 \mu \mathrm{gg}^{-1}$ (G30) of atracurium IV. Eyeball centralization time was measured; heart rate (HR), systolic (SAP), mean (MAP) and diastolic (DAP) arterial pressures, respiratory rate (RR), tidal volume (Vt) and minute volume $(\mathrm{Vm})$ were determined every $5 \mathrm{~min}$, and $\mathrm{pH}$, arterial $\mathrm{CO}_{2}$ pressure $\left(\mathrm{PaCO}_{2}\right)$, arterial $\mathrm{O}_{2}$ pressure $\left(\mathrm{PaO}_{2}\right)$, hemoglobin oxygen saturation $\left(\mathrm{SaO}_{2}\right)$ bicarbonate $\left(\mathrm{HCO}_{3}^{-}\right)$and base excess (BE) every $15 \mathrm{~min}$ until 60min. Both doses of atracurium produced a similar period of eyeball centralization. Vt in groups treated with atracurium was lower than in CG up to $15 \mathrm{~min}$. Vm in $G 15$ differed from CG up to $10 \mathrm{~min}$ and in $G 30$ up to $25 \mathrm{~min}$. No differences were observed for cardiovascular parameters, $\mathrm{RR}, \mathrm{SaO}_{2}, \mathrm{PaO}_{2}, \mathrm{HCO}_{3}^{-}$and $\mathrm{BE} . \mathrm{pH}$ decreased in $\mathrm{CG}$ between 30 and 60min and in $G 15$ and G30 at 15min. G30 differed from $\mathrm{CG}$ between 15 and $30 \mathrm{~min}$. $\mathrm{PaCO}$ in $\mathrm{GC}$ differed from baseline between 30 and 60min and in G15 differed at 15min. Atracurium at the dose of $15 \mu \mathrm{g} \mathrm{kg}^{-1}$ is adequate for short corneal procedures in inhalant-anesthetized dogs under spontaneous breathing.

Key words: dog, atracurium, spontaneous breathing, corneal ulcer.

\section{RESUMO}

Objetivou-se determinar os efeitos cardiopulmonares e o tempo de centralização do globo ocular obtidos com 15 ou $30 \mu \mathrm{g} \mathrm{kg}^{-1}$ de atracúrio em cães anestesiados sob ventilação espontânea. Dezoito cães adultos foram prémedicados com 0,1 $\mathrm{mg} \mathrm{kg}^{-1}$ de acepromazina e $0,5 \mathrm{mg} \mathrm{kg^{-1 }}$ de morfina IM, anestesiados com $4 m \mathrm{~kg}^{-1}$ de propofol IV e mantidos sob anestesia inalatória com isofluorano em ventilação espontânea. Os animais receberam $1 \mathrm{~mL}$ de $\mathrm{NaCl}$

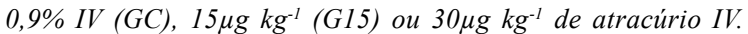
Mensuraram-se o tempo de centralização do globo ocular, a frequência cardíaca $(F C)$, as pressões arteriais sistólica (PAS), média (PAM) e diastólica (PAD), a frequência respiratória $(f)$, $o$ volume corrente $(V t)$ e o volume minuto $(V m)$ a cada $5 \mathrm{~min}$, e o pH, as pressões arteriais de $\mathrm{CO}_{2}\left(\mathrm{PaCO}_{2}\right)$ e $\mathrm{O}_{2}\left(\mathrm{PaO}_{2}\right)$, a saturação de oxigênio nas hemoglobinas $\left(\mathrm{SaO}_{2}\right)$ o bicarbonato $\left(\mathrm{HCO}_{3}^{-}\right)$e o excesso de base (BE) a cada 15min, até 60min. Ambas as doses de atracúrio produziram similar periodo de centralização. Os grupos tratados com atracúrio apresentaram menores valores para Vt até $15 \mathrm{~min}$. $\mathrm{O} \mathrm{Vm}$, no G15, diferiu do GC até 10 min e do G30 até 25min. Não foram observadas alterações nos parâmetros cardiovasculares $f, \mathrm{SaO}_{2}, \mathrm{PaO}_{2}$, $\mathrm{HCO}_{3}^{-}$e $\mathrm{EB}$. $\mathrm{O}$ pH diminuiu no $\mathrm{GC}$ entre 30 e $60 \mathrm{~min}$ e em $\mathrm{Gl}$ e G30 aos 15min. A PaCO elevou-se no GC entre 30 e 60 min e no G15 aos 15min. A dose de $15 \mu \mathrm{gg}^{-1}$ de atracúrio demonstrou ser adequada para centralização do globo ocular, podendo ser utilizada em procedimentos corneanos de curta duração em cães anestesiados com isoflurano e mantidos sob ventilação espontânea.

Palavras-chave: cão, atracúrio, ventilação espontânea, úlcera corneana.

IFaculdade de Zootecnia e Engenharia de Alimentos, Universidade de São Paulo (USP). Av. Duque de Caxias Norte, 225, 13635900, Pirassununga, SP, Brasil. E-mail: carregaro@usp.br. Autor para correspondência.

"Universidade Federal de Santa Maria (UFSM), Santa Maria, RS, Brasil.

IIIFaculdades Integradas do Planalto Central (FACIPLAC), Brasília, DF, Brasil. 


\section{INTRODUCTION}

Neuromuscular blocking agents are commonly utilized as adjuvants to general anesthetics to facilitate ventilation, and in thoracic, orthopedic and intraocular surgeries, in this case to produce centralization of the eyeball (GLOVER \& CONSTANTINESCU, 1997), keeping the cornea totally visible and thereby facilitating surgical procedures. However, there is the need of artificial ventilation due to respiratory paralysis.

The action of neuromuscular blocking agents is characterized by flaccid paralysis obtained at different speeds, depending on the body region. Generally, the oculomotor muscles are affected first, followed by the tail, oropharynx and limbs. The intercostals, diaphragm and abdominal muscles are the last ones to follow the sequence of paralysis. In summary, there is a progressive blockade, from the periphery to the center, where recovery occurs in reverse (HEMMERLING \& DONATI, 2003).

The choice of low doses of neuromuscular blockers has advantages if a selective paralysis could be achieved, permitting adequate ventilation while the eye is centralized (CARREGARO et al., 2006). This facilitates the performance of intraocular surgeries and diminishes risks to the anesthetized patient. Animals anesthetized on spontaneous breathing maintain cardiovascular function at better baselines than animals on controlled ventilation (HARTSFIELD, 1996), the latter impeding venous return to the right side of the heart, reducing cardiac output and arterial pressure. Besides, the procedure is less expensive because there is no need for specific equipment for the maintenance of ventilation.

Studies have demonstrated the possibility of utilizing low doses of neuromuscular blockers and maintenance of pulmonary function. In the analysis of respiratory depression and muscle relaxation in dogs treated with $10 \mu \mathrm{g} \mathrm{kg}^{-1}$ of pancuronium, eyeball centralization was achieved with moderate respiratory depression without however causing apnea and without the need for controlled ventilation in these animals (LEE et al., 1998).

Atracurium at a dose of $250 \mu \mathrm{g} \mathrm{kg}^{-1}$ causes total muscle blockade of $15-35 \mathrm{~min}$ of duration with minimal cardiovascular effects (HUGHES \& CHAPPLE, 1981). In a preliminary study (CARREGARO et al., 2006), three doses of atracurium $\left(25,50\right.$ and $\left.75 \mu \mathrm{g} \mathrm{kg}^{-1}\right)$ were tested and found to cause eyeball centralization without complete blockade of the intercostal and diaphragmatic muscles. The time of centralization increased with dose, that was 38,65 and $78 \mathrm{~min}$, respectively. However, there was an increase in end tidal $\mathrm{CO}_{2}\left(\mathrm{ETCO}_{2}\right)$ in the $50 \mu \mathrm{g} \mathrm{kg}^{-1}$ group for $5 \mathrm{~min}$ with a peak near $50 \mathrm{mmHg}$, and a stronger effect in the $75 \mu \mathrm{g}$ $\mathrm{kg}^{-1}$ group, with values almost as high as $60 \mathrm{mmHg}$ for $20 \mathrm{~min}$. The highly elevated $\mathrm{ETCO}_{2}$ values obtained indicated a blood gas analysis for the adequate determination of these values.

The aim of this study was to determine the effects of 15 or $30 \mu \mathrm{g} \mathrm{kg}^{-1}$ of atracurium on cardiopulmonary parameters and on the duration of eyeball centralization of anesthetized dogs under spontaneous breathing.

\section{MATERIALS AND METHODS}

For the study proposed, 18 mixed-breed dogs were utilized, 8 males and 10 females. The animals were considered healthy after performing clinical and ophthalmologic exam and laboratory tests (hemogram, urea, creatinine, alkaline phosphatase and alanine aminotransferase).

After $12 \mathrm{~h}$ solid and $4 \mathrm{~h}$ liquid fasting, animals were pre-medicated with $0.1 \mathrm{mg} \mathrm{kg}^{-1}$ acepromazine ${ }^{\mathrm{a}}$ and $0.5 \mathrm{mg} \mathrm{kg}^{-1}$ morphine ${ }^{\mathrm{b}} \mathrm{IM}$. After $15 \mathrm{~min}$, the arms were shaven, and cephalic venopuncture was performed by a $22 \mathrm{G}$ catheter, which $0.9 \% \mathrm{NaCl}$ was administered at a rate of $10 \mathrm{~mL} \mathrm{~kg} \mathrm{~h}^{-1}$ during the whole period of evaluation. Later, the animals were anesthetized with $4 \mathrm{mg} \mathrm{kg}^{-1}$ propofol ${ }^{\mathrm{c}} \mathrm{IV}$, intubated with an orotracheal tube of suitable diameter and maintained under inhalant anesthesia with isoflurane $\mathrm{d}^{\mathrm{d}}$ in $1 \mathrm{~L} \mathrm{~min}^{-1}$ of $100 \% \mathrm{O}_{2}$ in a circular valvular circuit. The animals were positioned in sternal recumbency during the period of evaluation. By controlling vaporization, the animals were maintained in stage III/2 of anesthesia, characterized mainly by the total rotation of the eyeball and by the presence of the slight palpebral reflex (MOENS \& COPPENS, 2007), which requires a vaporization of 1 to $1.5 \%$. Immediately after the establishment of inhalant anesthesia, instrumentation of the animals was initiated.

The right podal dorsal artery was catheterized using a $22 \mathrm{G}$ catheter. This was connected to a 3-way stopcock and a pressure transducer filled with heparinized solution, positioned and zeroed at the level of the heart to measure mean arterial pressure (MAP), systolic arterial pressure (SAP) and diastolic arterial pressure (DAP), in mmHg. The electrodes were positioned in the axillary and the groin regions to determine heart rate (HR) in beats per minute (bpm) and rhythm, based on lead II. Cardiovascular parameters were evaluated by a multiparametric monitor ${ }^{\mathrm{e}}$. 
The ventilometer ${ }^{\mathrm{f}}$ was connected to the tracheal tube, to measure tidal volume $(\mathrm{Vt})$ and minute volume $(\mathrm{Vm})$, in $\mathrm{mL}$. The respiratory rate $(\mathrm{RR})$ was measured by visualization of the reservoir bag, in breaths per minute (bpm). Body temperature $\left(\mathrm{T}^{\circ} \mathrm{C}\right)$ was maintained between 36 and $37^{\circ} \mathrm{C}$ for the whole period of evaluation with the aid of a thermal mattress.

After the 30min period for instrumentation and stabilization of the vaporization and physiological parameters, the animals were randomized and equally assigned to one of three treatments $(n=6)$ : control $(\mathrm{CG})$ with the administration $1 \mathrm{~mL} 0.9 \% \mathrm{NaCl} \mathrm{IV}$; and two with atracurium ${ }^{\mathrm{g}}$ at $15 \mu \mathrm{g} \mathrm{kg}^{-1}$ (G15) and $30 \mu \mathrm{g} \mathrm{kg}^{-1}$ (G30) $\mathrm{IV}$, diluted in $0.9 \% \mathrm{NaCl}$ and standardized to a final volume of $1 \mathrm{~mL}$. The animals in G15 and G30 were submitted to a surgical procedure for establishing a corneal ulcer model as a part of a different research. In the CG animals, it was not possible to carry out the same surgical procedure since centralization of the eyeball was not achieved.

The physiological parameters were measured by two observers blinded to the treatments. HR, RR, MAP, SAP, DAP, Vt, and Vm were determined immediately before the administration of atracurium (time 0 ) and every $5 \mathrm{~min}$ after the administration of the treatment up to $60 \mathrm{~min}$. Blood gas analysis was performed at time 0 and every $15 \mathrm{~min}$ of evaluation. Blood samples $(1 \mathrm{~mL})$ were anaerobically drawn with a previously heparinized syringe from the podal dorsal artery with the help of a 3-way stopcock connected to the catheter, discarding the first milliliter with another syringe. Arterial $\mathrm{CO}_{2}$ pressure $\left(\mathrm{PaCO}_{2}\right)$, arterial $\mathrm{O}_{2}$ pressure $\left(\mathrm{PaO}_{2}\right), \mathrm{pH}$, bicarbonate $\left(\mathrm{HCO}_{3}^{-}\right)$, bases excess (BE) and hemoglobin oxygen saturation $\left(\mathrm{SaO}_{2}\right)$ were obtained immediately after the collection. The eyeball centralization time was determined as the time from initial centralization of the eyeball (after the administration of atracurium) until the eyeball became semi-rotated. At the end of the evaluation period, $0.2 \mathrm{mg}$ $\mathrm{kg}^{-1}$ meloxicam ${ }^{\mathrm{h}} \mathrm{SC}$ was administered to provide postoperative analgesia.

Statistical analysis was performed using the GraphPad Prism 4 program ${ }^{i}$. Repeated measure analysis of variance (ANOVA) was used followed by Bonferroni test for comparisons of means within each group in relation to time zero. For comparison between groups, at each time, one-way ANOVA was performed followed by Tukey's test if necessary. For comparisons regarding the time of eyeball centralization, ordinary ANOVA was utilized, followed by the Kruskal-Wallis test. The differences were considered significant when $\mathrm{P}<0.05$. The parametric results are expressed as means \pm standard deviation and the non-parametric as medians and interquartile ranges.

\section{RESULTS}

There was no difference in body weight between groups, which CG, G15 and G30 obtained weight of $14.8 \pm 2.2 \mathrm{~kg}, 14.5 \pm 3.1 \mathrm{~kg}$ and $14.0 \pm 3.1 \mathrm{~kg}$, respectively. Eyeball centralization was observed in all the animals of the groups treated with atracurium. There was no significant difference between G15 and G30, where median and interquartile range (IQR) of neuromuscular blockade was $42.5(10,60)$ and $47.5(20$, $60)$ min, respectively (Figure 1). Both groups differed significantly from $\mathrm{CG}$, which did not show eyeball centralization at any moment.

In relation to the cardiovascular parameters, there were no differences between the groups at any moment, or any group compared to time zero (Figure 2 ). In addition, no alterations in heart rhythm were observed in any group. There was no statistical difference between groups or in each group when compared to basal levels for RR (Figure 2) and $\mathrm{SaO}_{2}$ (Table 1). Vt in G15 and G30 were statistically lower than in CG up to $15 \mathrm{~min}$ after drug administration (Figure 2). Similarly, both groups showed a decline in Vt in relation to their baseline values up to $10 \mathrm{~min}$. In the analysis of Vm (Figure 2), G15 differed from CG up to $10 \mathrm{~min}$ and $\mathrm{G} 30$ differed from CG up to $25 \mathrm{~min}$ of evaluation. Both groups differed from zero moment only at $5 \mathrm{~min}$.

With regard to $\mathrm{pH}$, there was a decrease in relation to baseline values in CG between 30 and $60 \mathrm{~min}$ and in G15 and G30, only at $15 \mathrm{~min}$ (Table 1). G30 also differed from $\mathrm{CG}$ at 15 and $30 \mathrm{~min}$. In relation to baseline values of $\mathrm{PaCO}_{2}$ (Table 1), CG differed between 30 and $60 \mathrm{~min}$ and $\mathrm{G} 15$ differed at $15 \mathrm{~min} . \mathrm{PaO}_{2}$, bicarbonate and

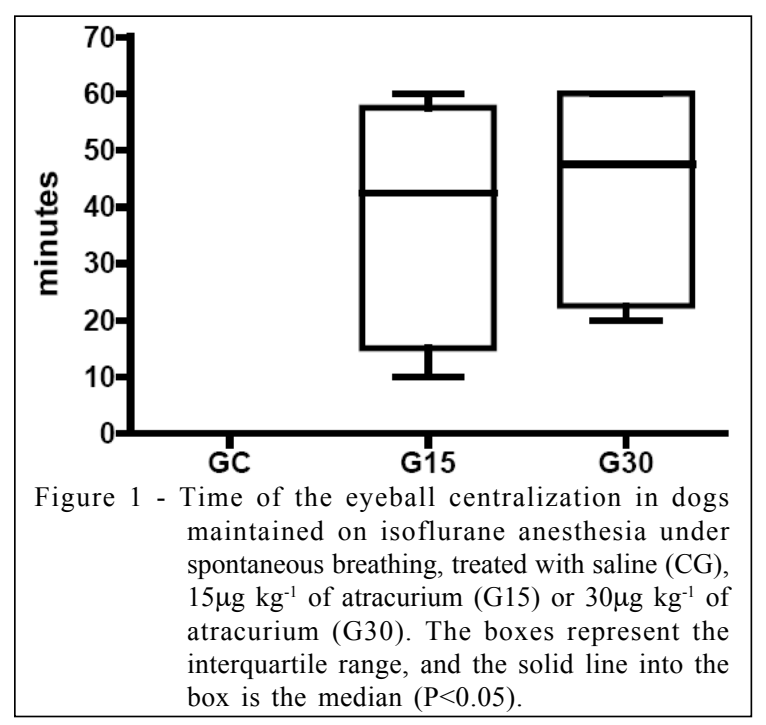

Ciência Rural, v.40, n.7, jul, 2010. 

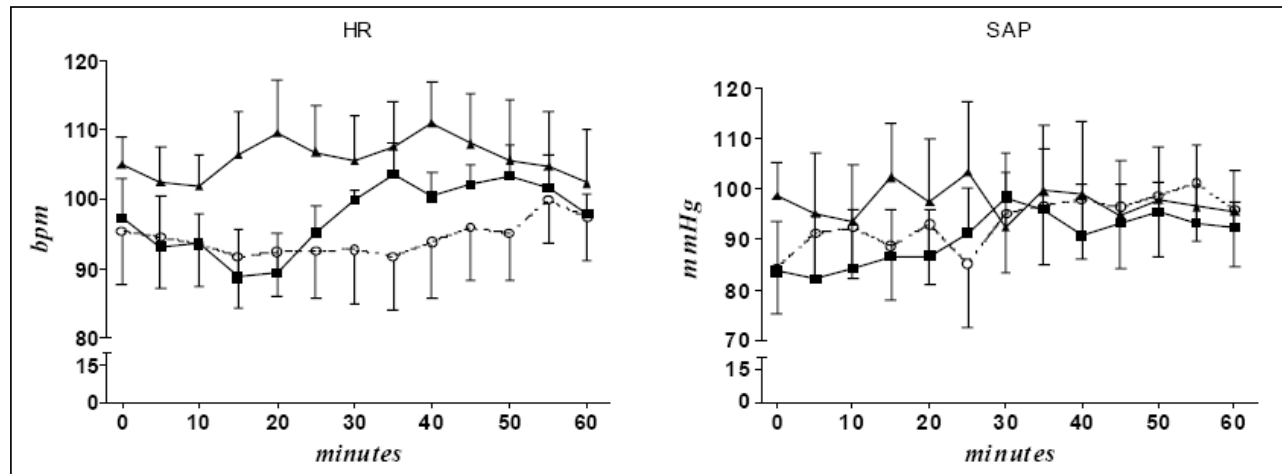

MAP

DAP
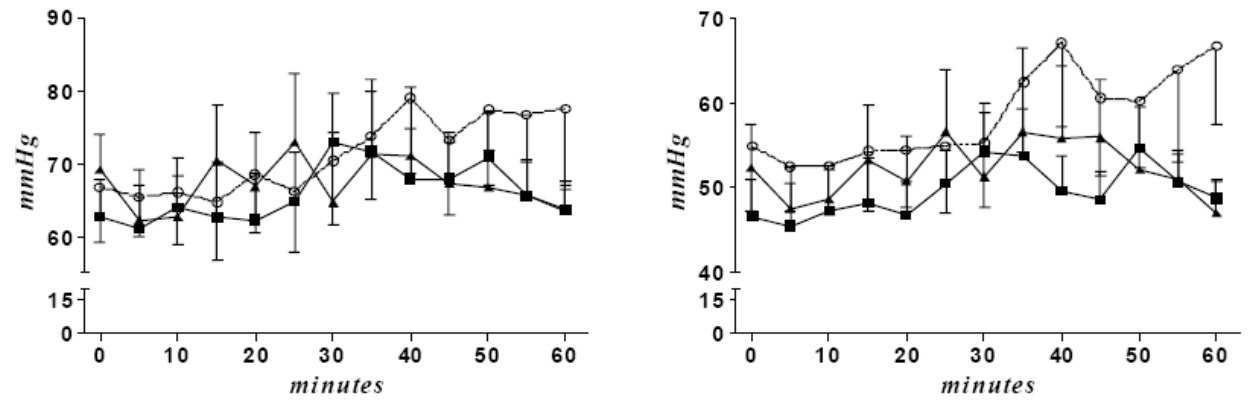

$\mathrm{Vt}$

$\mathrm{Vm}$
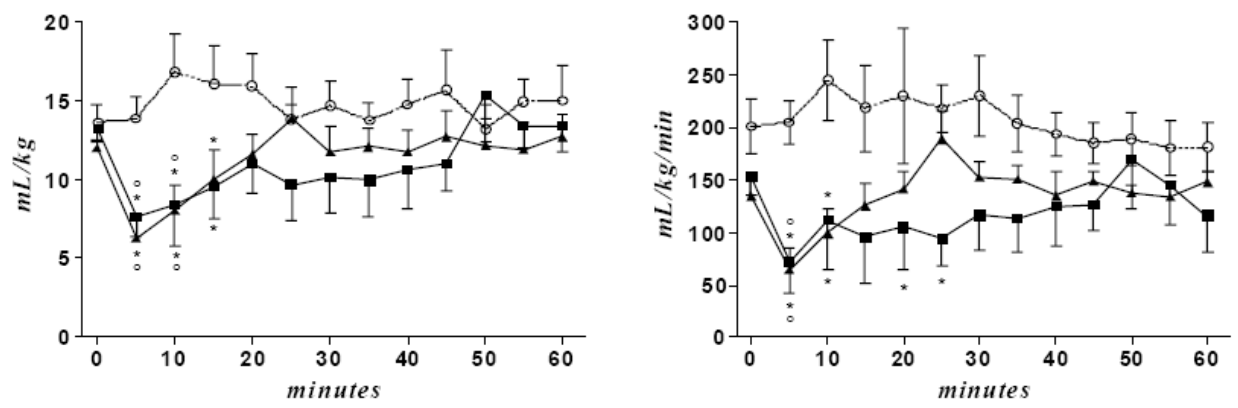

RR
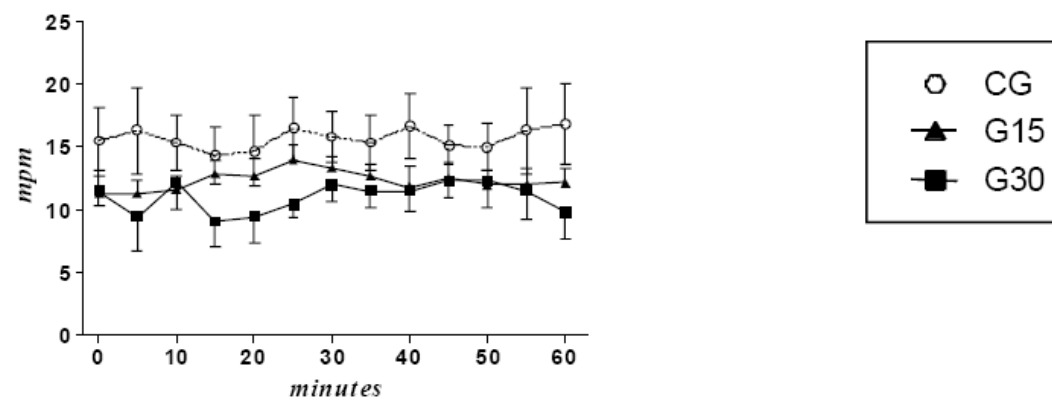

Figure 2 - Cardiorrespiratory parameters (mean \pm error deviation) evaluated in dogs ( $\mathrm{n}=6$ each group) maintained on isoflurane anesthesia under spontaneous breathing, treated with saline (CG), $15 \mu \mathrm{g} \mathrm{kg}^{-1}$ of atracurium (G15) or $30 \mu \mathrm{g} \mathrm{kg}^{-1}$ of atracurium (G30). * Statistical difference in relation to time $0(\mathrm{P}<0.05)$. ${ }^{\circ}$ Statistical difference from $\mathrm{CG}(\mathrm{P}<0.05)$. (HR - heart rate; SAP - systolic arterial pressure; MAP - mean arterial pressure; DAP - diastolic arterial pressure; Vt - tidal volume; Vm - minute volume; RR - respiratory rate). 
Table 1 - Blood gas parameters (mean \pm standard deviation) evaluated in dogs $(n=6$ each group) maintained on isoflurane anesthesia under

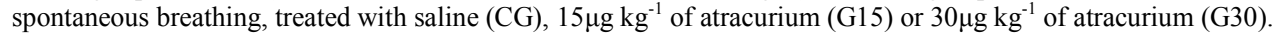

\begin{tabular}{|c|c|c|c|c|c|c|}
\hline \multirow{2}{*}{ Parameter } & \multicolumn{6}{|c|}{ 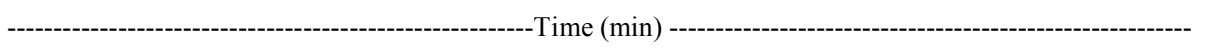 } \\
\hline & Group & 0 & 15 & 30 & 45 & 60 \\
\hline \multirow{3}{*}{$\mathrm{pH}$} & CG & $7.29 \pm 0.03$ & $7.27 \pm 0.03$ & $7.26 \pm 0.03 *$ & $7.26 \pm 0.03 *$ & $7.25 \pm 0.02 *$ \\
\hline & G15 & $7.25 \pm 0.05$ & $7.17 \pm 0.13 *$ & $7.23 \pm 0.06$ & $7.23 \pm 0.04$ & $7.24 \pm 0.05$ \\
\hline & G30 & $7.23 \pm 0.08$ & $7.11 \pm 0.13 * \circ$ & $7.13 \pm 0.14^{\circ}$ & $7.12 \pm 0.17$ & $7.18 \pm 0.08$ \\
\hline \multirow{3}{*}{$\begin{array}{l}\mathrm{PaO}_{2} \\
(\mathrm{mmHg})\end{array}$} & $\mathrm{CG}$ & $376 \pm 50$ & $403 \pm 48$ & $402 \pm 43$ & $419 \pm 27$ & $426 \pm 47$ \\
\hline & G15 & $446 \pm 83$ & $427 \pm 75$ & $467 \pm 96$ & $489 \pm 89$ & $442 \pm 68$ \\
\hline & G30 & $431 \pm 46$ & $478 \pm 22$ & $486 \pm 48$ & $479 \pm 48$ & $504 \pm 35$ \\
\hline \multirow{3}{*}{$\begin{array}{l}\mathrm{PaCO}_{2} \\
(\mathrm{mmHg})\end{array}$} & $\mathrm{CG}$ & $45 \pm 4$ & $48 \pm 4$ & $49 \pm 4^{*}$ & $49 \pm 5^{*}$ & $50 \pm 3^{*}$ \\
\hline & G15 & $51 \pm 7$ & $58 \pm 10 *$ & $54 \pm 7$ & $54 \pm 6$ & $53 \pm 8$ \\
\hline & G30 & $53 \pm 10$ & $73 \pm 23$ & $63 \pm 16$ & $68 \pm 24$ & $67 \pm 19$ \\
\hline \multirow{3}{*}{$\begin{array}{l}\mathrm{HCO}_{3}^{-} \\
\left(\mathrm{mmol} \mathrm{L}^{-1}\right)\end{array}$} & $\mathrm{CG}$ & $21.3 \pm 1$ & $21.6 \pm 1$ & $21.9 \pm 1.2$ & $21.6 \pm 1.4$ & $21.7 \pm 1.3$ \\
\hline & G15 & $22.1 \pm 1.5$ & $22.9 \pm 1.6$ & $22.2 \pm 0.9$ & $22.2 \pm 1.1$ & $22.2 \pm 1.2$ \\
\hline & G30 & $23.3 \pm 2.5$ & $24.9 \pm 3.7$ & $24.1 \pm 3.3$ & $24.9 \pm 3.9$ & $23.9 \pm 2.3$ \\
\hline \multirow{3}{*}{$\begin{array}{l}\mathrm{SaO}_{2} \\
(\%)\end{array}$} & $\mathrm{CG}$ & $98 \pm 1$ & $99 \pm 0.6$ & $99 \pm 0.5$ & $99 \pm 0.4$ & $98 \pm 1$ \\
\hline & G15 & $98 \pm 1$ & $98 \pm 1$ & $98 \pm 0.4$ & $99 \pm 0.3$ & $97 \pm 0.7$ \\
\hline & G30 & $98 \pm 1$ & $99 \pm 0.3$ & $99 \pm 0.3$ & $99 \pm 0.3$ & $99 \pm 0.2$ \\
\hline \multirow{3}{*}{$\mathrm{BE}$} & $\mathrm{GC}$ & $-5.2 \pm 0.9$ & $-5.6 \pm 1$ & $-5.4 \pm 1$ & $-5.7 \pm 1.2$ & $-5.5 \pm 1.2$ \\
\hline & G15 & $-5.1 \pm 1.7$ & $-6.2 \pm 2.4$ & $-5.6 \pm 1.5$ & $-5.6 \pm 1.2$ & $-5.3 \pm 1.2$ \\
\hline & G30 & $-4.75 \pm 1.7$ & $-6 \pm 1.2$ & $-6.5 \pm 1.6$ & $-6 \pm 1.3$ & $-5.1 \pm 1$ \\
\hline
\end{tabular}

${ }^{*}$ Statistical difference in relation to time $0(\mathrm{P}<0.05)$.

Statistical difference from $\mathrm{CG}(\mathrm{P}<0.05)$.

EB showed no differences in any group, in baseline evaluation as well as after the treatments (Table 1).

\section{DISCUSSION}

The doses of atracurium utilized were effective in blocking the extrinsic muscles of the eyeball, causing total exposure of the cornea for an adequate period. Because of the time obtained (42.5 and 47.5 min), these doses make it possible to carry out various ophthalmic surgeries. The fact that no eyeball centralization occurred in $\mathrm{CG}$ demonstrates that centralization requires exclusively the use of a peripheral muscle relaxant, but it can be intensified by the concomitant use of inhalat anesthesia (KASTRUP et al., 2005)

Cardiovascular parameters were maintained within the physiological range. Atracurium causes alterations in these parameters only at high doses, potentially leading to hypotension and tachycardia, due to the release of histamine (MARTINEZ, 1999). Furthermore, neuromuscular blockers cause tachycardia due to an antivagal action (STENLAKE \& HUGHES, 1987), but atracurium produces greater cardiovascular stability when compared to other blockers (HACKETT et al., 1989).

In relation to $\mathrm{SaO}_{2}$, all animals showed values over $97 \%$. This parameter does not represent the quantity of $\mathrm{O}_{2}$ available to tissues, but permits the determination of arterial oxygenation, which is indicative of alterations that can cause risk of hypoxia for the patient (JONES, 1996). There was no hypoxemia associated with any of the groups studied because the animals were supplemented with $100 \%$ oxygen, besides being healthy and without any lung pathology.

$\mathrm{PaO}_{2}$ supplies information on the efficacy of oxygenation of the lungs (HASKINS, 1996). Despite there being no statistical difference among the groups studied in relation to $\mathrm{PaO}_{2}, \mathrm{CG}$ showed at all times lower values than those considered normal for dogs submitted to inhalant anesthesia in $100 \% \mathrm{O}_{2}$ with spontaneous breathing (McDONELL, 1996). The groups treated with atracurium showed physiologic levels or very close, as it is anticipated in healthy subjects. 
Vt was lower up to $15 \mathrm{~min}$ in the groups treated with atracurium, when compared to $\mathrm{CG}$, but considering the physiologic range, which is 10 to $20 \mathrm{~mL}$ $\mathrm{kg}^{-1}$ (HASKINS, 1996), this variable showed a decline in G30 from 5 to $45 \mathrm{~min}$ and in G15 only up to $15 \mathrm{~min}$. Since there was a reduction in $\mathrm{Vm}$ without occurrence of bradypnea in animals treated with atracurium, mainly in G30, a decrease in respiratory amplitude occurred, with consequent hypercapnia and decrease in $\mathrm{pH}$.

Since $\mathrm{CO}_{2}$ diffuses easily through alveolar capillaries, the alveolar $\mathrm{CO}_{2}$ tension and $\mathrm{PaCO}_{2}$ are essentially the same. As a result, the measure of $\mathrm{PaCO}_{2}$ provides direct information on the sufficiency of alveolar ventilation (DIBARTOLA \& MORAIS, 1992). Despite that the $\mathrm{PaCO}_{2}$ values were higher than physiological levels in all the groups evaluated, there was no significant difference between them, indicating that the administration of atracurium was not the only cause of the elevation of this parameter. Elevated $\mathrm{PaCO}_{2}$ caused a reduction in $\mathrm{pH}$, and clinical acidosis was observed in all groups, including CG. The results observed in G15 showed acidosis only up to $15 \mathrm{~min}$, being equal to $C G$ after on. Those values demonstrate that the inhalant procedure was the most important cause for the acidosis. Inhalant anesthesia is one of the most common causes of respiratory acidosis (ROBERTSON, 1989; MUTOH et al., 1997), that can increase the action of peripheral muscle relaxants (ONO et al., 1988).

It should be pointed out that, although the use of atracurium at low doses does not cause apnea, the reversal of the blockade after doing the procedure is recommended, since the oropharynx muscles are blocked subsequently as the oculomotor muscles, which is associated with an increased risk of aspiration pneumonia. Moreover, the residual neuromuscular blockade is frequently observed after the end of general anesthesia, impairing the recovery of the patient (MURPHY, 2006). Also, the use of controlled or assisted ventilation and monitoring with Train of Four must be considered, to make procedures which use neuromuscular blockers safer.

\section{CONCLUSION}

Both doses of atracurium produced a similar period of eyeball centralization without cardiovascular alterations and bradypnea, but with respiratory acidosis. We suggest that the dose of $15 \mu \mathrm{g} \mathrm{kg}^{-1}$ of atracurium is adequate for short corneal procedures in inhalant-anesthetized dogs under spontaneous breathing.

\section{SOURCES AND MANUFACTURERS}

a- Acepran 1\%, Univet Indústria Veterinária S.A., Cambuci, SP, Brazil.

b- Dimorf, Cristália Produtos Químicos and Farmacêuticos Ltda, Itapira, SP, Brazil.

c- Diprivan 1\%, AstraZeneca do Brasil, Cotia, SP, Brazil.

d- Isoforine, Cristália Produtos Químicos and Farmacêuticos Ltda, Itapira, SP, Brazil

e- PM-9000 Express - Mindray® Medical Intenational Ltd, Shenzhen, China.

f- Ventilometer Narcosul, Narcosul, Porto Alegre, RS, Brazil. g- Tracrium, GlaxoSmithKline Brasil Ltda, Rio de Janeiro, RJ, Brazil.

h- Maxicam 0.2\%, Ourofino, Ribeirão Preto, SP, Brazil.

i- GraphPad Prism, GraphPad Software Inc, San Diego, California, USA.

\section{ETHICS COMMITTEE}

This work was approved by the Institutional Animal Care Committee, under process number 81-2006.

\section{REFERENCES}

CARREGARO, A.B. et al. Uso de atracúrio para o bloqueio da musculatura extrínseca do bulbo ocular em cães submetidos à anestesia inalatória sob ventilação espontânea. Arquivo Brasileiro de Medicina Veterinária e Zootecnia, v.58, n.6, p.1057-1063, 2006. Available from: $<$ http://www.scielo.br/scielo.php?pid=s010209352006000600013\&script=sci_arttext $>$. Accessed: Jun 10, 2010. doi: $10.1590 / \mathrm{S} 0102-09352006000600013$.

DIBARTOLA, S.P.; MORAIS, H.S.A. Respiratory acid-base disorders. In: DIBARTOLA, S.P. Fluid therapy in small animal practice. Philadelphia: Saunders, 1992. Cap.10, p.258-275.

GLOVER, T.L.; CONSTANTINESCU, G.M. Surgery for cataracts. Veterinary Clinics of North America Small Animal Practice, v.27, n.5, p.1143-1174, 1997.

HACKETT, G.H. et al. Cardiovascular effects of vecuronium, atracurium, pancuronium, metocurine and RGH-4201 in dogs. Acta Anaesthesiologica Scandinavica, v.33, n.4, p.298303, 1989 .

HARTSFIELD, S.M. Airway management and ventilation. In: THURMON, J.C. et al. Lumb \& Jones' veterinary anesthesia. 3.ed. Baltimore: Lea \& Febiger, 1996. Cap.17, p. 515-556.

HASKINS, S.C. Monitoring the anesthetized patient. In: THURMON, J.C. et al. Lumb \& Jones' veterinary anesthesia. 3.ed. Baltimore: Lea \& Febiger, 1996. Cap.15, p.409-424.

HEMMERLING, T.M.; DONATI, F.D. Neuromuscular blockade at the larynx, the diaphragm and the corrugators supercilli muscle: a review. Canadian Journal of Anesthesia, v.50, n.8, p.779794, 2003. Available from: <http://www.springerlink.com/ content/p20187p2018148hk/fulltext.pdf>. Accessed: Jun 10, 2010 . 
HUGHES, R.; CHAPPLE, D.J. The pharmacology of atracurium: a new competitive neuromuscular blocking agent. British Journal of Anaesthesia, v.53, n.1, p.31-44, 1981.

JONES, J.L. Noninvasive monitoring techniques in anesthetized animals. Veterinary Medicine, v.91, n.4, p.326-335, 1996.

KASTRUP, M.R. et al. Neuromuscular blocking properties of atracurium during sevoflurane or propofol anaesthesia in dogs. Veterinary Anaesthesia and Analgesia, v.32, n.4, p.222227, 2005. Available from: <http://www3.interscience.wiley.com/ cgi-bin/fulltext/118670420/PDFSTART>. Accessed: Jun 10, 2010. doi: $10.1111 /$ j.1467-2995.2005.00240.x.

LEE, D.D. et al. Respiratory depressant and skeletal muscle relaxant effects of low-dose pancuronium bromide in spontaneously breathing isoflurane-anesthetized dogs. Veterinary Surgery, v.27, n.5, p.473-479, 1998.

MARTINEZ, E.A. Newer neuromuscular blockers. Veterinary Clinics of North America Small Animal Practice, v.29, n.4, p.811-817, 1999 .

McDONELL, W. Respiratory system. In: THURMON, J.C. et al. Lumb \& Jones' veterinary anesthesia. 3.ed. Baltimore: Lea \& Febiger, 1996. Cap.6, p.115-147.
MOENS, Y.; COPPENS, P. Patient monitoring and monitoring equipment. In: SEYMOUR, C.; DUKE, T. BSAVA Manual of canine and feline anaesthesia and analgesia. 2.ed. Quedgeley: British Small Animal Veterinary Association, 2007. Cap.7, p.62-79.

MURPHY, GS. Residual neuromuscular blockade: incidence, assessment, and relevance in the postoperative period. Minerva Anestesiologica, v.72, n.3, p.97-109, 2006. Available from: <http://www.minervamedica.it/ en/freedownload.php?cod=R02Y2006N03A0097>. Accessed: Jun 10, 2010 .

MUTOH, T. et al. Cardiopulmonary effects of sevoflurane, compared with halothane, enflurane, and isoflurane, in dogs. American Journal of the Veterinary Research, v.58, n.8, p.885-890, 1997.

ONO, K. et al. The influence of respiratory-induced acid-base changes on the action of non-depolarizing muscle relaxants in rats. Anesthesiology, v.68, n.3, p.357-362, 1988.

ROBERTSON, S.A. Simple acid-base disorders. Veterinary Clinics of North America Small Animal Practice, v.19, n.2, p.289-306, 1989.

STENLAKE, J.B.; HUGHES, R. In vitro degradation of atracurium in human plasma. British Journal of Anaesthesia, v.59, n.6, p.806-807, 1987. 